\title{
Carbon Performance Evaluation Indicators based on Resource Value Flow
}

\author{
Cai-ping ZHANG ${ }^{\mathrm{a}, *}$ \\ University of South China, Hunan, Hengyang, China, \\ 421001 \\ a871758842@qq.com
}

\author{
Ying ZHANG ${ }^{\mathrm{b}}$ \\ University of South China, Hunan, Hengyang, \\ China, 421001 \\ b1508084867@qq.com
}

\begin{abstract}
Carbon performance evaluation indicators are made up of carbon cost efficiency, carbon economic efficiency, carbon reduction efficiency and carbon intensity according to the theories and methods of resource value flow. The results shows that carbon performance evaluation indicators for the perspective of resource value flow can improve carbon resource efficiency, identify the key source of carbon emission and compare carbon cost and benefit and provide decision related information for interest related parties.
\end{abstract}

Keywords-resource value flow; carbon performance; evaluation indicators; carbon reduction

\section{INTRODUCTION}

Serious economic consequences, caused by climate change has aroused worldwide attention, signing of the Kyoto Protocol (1997), the Copenhagen Accord (2009) and the Paris Agreement (2015) fully shows the determination and efforts of governments around the world to tackle climate change and develop low-carbon economy. The participation of enterprises is the key point to address climate change and develop low-carbon economy. In order to give full play to the enterprises' initiative in the development of low-carbon economy, the government need to legislate a series of laws, regulations, policies and measures, enterprises also need to build a corresponding system to motivate and constraint enterprises' behavior of carbon emissions. The carbon performance evaluation system is one of them. However, throughout the domestic and foreign present research situation, there is no exist a set of accepted standards for carbon performance evaluation, and lack of case analysis application in carbon performance evaluation. According to this situation, the author try to build the carbon performance evaluation index, according to the characteristics of the low carbon management, based on the domestic and overseas research production and guided by the theories and methods of the resource value flow, to evaluate carbon performance in steel enterprise.

\section{RESOURCE VALUE FLOW REVIEW}

Originated in the Material Flow Cost Accounting (MFCA), the resource value flow calculation is a kind of environmental management accounting method, which aims to reduce environmental impact load and improve the effective utilization of resources value, measures the stock flow of material and energy resources using monetary and material object at the same time, through calculating resources consumed by defected products, waste and other emissions in each manufacturing process and convert them into monetary value, supports business executives and onsite managements to make related decision. Xiao and Jin (2008) has first proposed Resource Value Flow Accounting concept and its application, expands the accounting management object from a single value movement to the sustainable development of combining resource circulation and value circulation. Based on confluent analysis mechanism of resources material flow and value flow, Xie (2012) builds the basic theory and method system applied in resources value flow analysis of the coal industry circulation economy. Zhao (2012) builds carbon emissions cost accounting and evaluation system in the iron and steel enterprise, based on resources value flow theory, the unit process "flow" analysis and value engineering theory system. Tang and Zhang (2013) applied the Resource Value Accounting to the calculation of the carbon emissions cost, resource and energy consumption leads to direct carbon emissions and outsourcing of energy consumption leads to indirect emissions. On the basis of the material flow and value flow interaction influence rule of circular economy, Xiong and Xiao (2014) starts with dynamic changes such increase and decrease processes of the material flow routes, "tracking" to describe resources value flow, adopt measures such multidisciplinary cost, revenue, profits and environmental damage value to build a performance measurement index system of circular economy based on value flow.

Referencing to the above research results found that carbon performance evaluation index, based on the resource value flow method, aim at the whole life cycle of product, that is using the method of material flows tracking trace enterprise's carbon emissions and carbon-based material flows. Through continuously, dynamically and comprehensively reveal value flow information of carbonbased materials, it play an important role in flow route optimization, upgrading of the decision to reduce emissions, controlling and performance evaluation of carbon emissions activities in the iron and steel enterprise production operation process.

\section{III.THE CONSTRUCTION OF CARBON PERFORMANCE EVALUATION METHOD BASED ON RESOURCE VALUE FLOW}

Based on the theory of the low carbon economy, the resource value flow analysis method analyze product cost 
transferred by value in the process of the flow of the material, and then upgrades the technology and improve production efficiency to lower resource consumption, at the same time considers unexpected output of $\mathrm{CO}_{2}$ in the material flow process. According to the resource value flow analysis, establishing the basic principle of carbon performance evaluation indexes is regards carbon materials as input resources, analyzes its value shifting and carbon emissions in the process of product manufacturing and transferring, while considers the indirect carbon emissions generated by outsourcing energy. Referring the concept of positive and negative products in resource value flow, we can regards $\mathrm{CO}_{2}$ as the negative products in the production process, and then share carbon emissions of each process with positive products, that is qualified products of each process. This classification method can not only analysis real carbon emission levels of positive products, also explicitly obtain carbon emissions data belonging to enterprise manufacturing process improvement or technology upgrade. The management can reform the relevant process to reduce the overall carbon emissions.

Carbon performance evaluation method based on resource value flow could calculate carbon emission via analyzing material flow among all the production process and external damage cost of carbon dioxide. Material flow also add value to the products then we would relate the value of positive products with cost of carbon emission. The author has established four carbon performance indicators:

\section{A. Carbon Cost Efficiency}

Cost Efficiency of Carbon Emission is equal to resources cost/cost of carbon emissions. The extensive mode of economic development pursued rapid growth while neglected the environmental load capacity. Governments all over the world has increasingly concerned the greenhouse effect, china is not exceptional. Our government puts forward a series of development policy to promote enterprise transformation. Iron and steel enterprises as traditional "Three-High" enterprise have been the main force of energy saving and emission reduction. Resources input cost of iron and steel enterprise includes materials, energy, equipment depreciation cost for production such as steel consumption including. Cost efficiency of carbon emission referred to iron and steel enterprises is the ratio of carbon emissions cost and cost of resources, which reveals how much value of resource per unit cost of carbon emission consumed.

\section{B. Carbon Economic Efficiency}

Economic Efficiency of Carbon Emission is the ratio of carbon emissions cost and product value, which refers to emission cost caused by per unit of product. So managers would be able to improve efficiency of resource utilization or production of positive products via upgrading technology and innovation. In addition to raw materials, energy cost and other ordinary cost, emission cost is supposed to included considering the inevitability of emitting greenhouse gas along the production process.

\section{Carbon Reduction Efficiency}

This indicator is $\mathrm{CO}_{2}$ emissions/resource cost, which means per unit consumption of resource relate to products or services causes greenhouse gas emission. As though emission cost would be influenced by price fluctuation from the carbon trading market, it can't reflect the physical emission reduction. So this indicator compared resource input cost and carbon emissions to reflect carbon reduction efficiency based on the value of resource.

\section{Carbon Emission Intensity}

This indicator divided $\mathrm{CO} 2$ emissions by positive product value, which points to carbon emissions caused by per unit product. To compare material flow and value flow of each working procedure in enterprise, managers could analyze improvement of resource value flow efficiency to identify key links and consider the influence of products in entire life cycle.

\section{APPLICATION ANALYSIS OF CARBON PERFORMANCE EVALUATION IN IRON AND STEEL ENTERPRRISE}

\section{A. Status quo of Carbon Emissions in Baosteel}

Baosteel group company sole founded Baosteel co., LTD.on February 3, 2000. Now, Baosteel group company which owned three kinds of product: general carbon steel, stainless steel and special steel product has Baosteel, Baosteel stainless steel, Baosteel special steel, Shaoguan steel and Bayi steel, five steel companies in total. Baosteel co., LTD. emitted 35.5025 million ton greenhouse gas in 2013. The overall emissions of group company was 45.5289 million tons, while Baosteel group company was allocated 48.0737 million tons carbon quotas. However, there were three companies, Baori car plate, fifth steel gas and Baosteel new material, emitted excess emissions, which was less than 30000 tons in total. Other companies managed to emit carbon dioxide under restriction. Baosteel group corporation will receive gradually less carbon emission quotas to restrain enterprise carbon emissions, considering its industry characteristics like resource intensive, mass energy consumption and great environmental load. In order to stay leading position, they need to upgrade production process as soon as possible and apply green and sustainable development conception in operating management. For example, Baosteel hot rolling reheating furnace could pump heated steam into low-pressure pipe network of another factory by recycling waste heat, so as to save energy and reduce energy consumption. 
TABLE I. CARBON TRADING STATUS IN BAOSTEEL IN 2013

\begin{tabular}{|c|c|c|c|c|}
\hline Baosteel & $\begin{array}{c}\text { quotas } \\
\text { (million } \\
\text { ton) }\end{array}$ & $\begin{array}{c}\text { real } \\
\text { emission } \\
\text { (million } \\
\text { ton) }\end{array}$ & $\begin{array}{c}\text { surplus } \\
\text { (million } \\
\text { ton) }\end{array}$ & $\begin{array}{c}\text { revenue } \\
\text { (million } \\
\text { yuan) }\end{array}$ \\
\hline Baosteel & 37.74 & 35.50 & 0.11 & 212.92 \\
\hline $\begin{array}{c}\text { Bao } \\
\text { stainless }\end{array}$ & 6.30 & 6.30 & 0 & 0.25 \\
\hline $\begin{array}{c}\text { Bao } \\
\text { specialsteel }\end{array}$ & 1.22 & 0.92 & 29.94 & 0 \\
\hline $\begin{array}{c}\text { Baori car } \\
\text { plate }\end{array}$ & 0.58 & 0.59 & -0.8 & 0.03 \\
\hline $\begin{array}{c}\text { Baosteeche } \\
\text { mistry }\end{array}$ & 0.77 & 0.74 & 0 & 2.83 \\
\hline $\begin{array}{c}\text { Fifthsteel } \\
\text { gas }\end{array}$ & 0.11 & 0.11 & -0.7 & 0.06 \\
\hline $\begin{array}{c}\text { Bao new } \\
\text { material }\end{array}$ & 0.10 & 0.12 & -1.29 & 0.13 \\
\hline $\begin{array}{c}\text { Weisteel } \\
\text { energy }\end{array}$ & 1.25 & 1.25 & 0 & 0.01 \\
\hline Total & 48.07 & 45.53 & 38.15 & 216.22 \\
\hline
\end{tabular}

\section{B. Analysis of Carbon Performance Evaluation of} Baosteel Based on Resource Value Flow

Managers could analyze either dynamic situation of resource value flow among processes in one procedure by calculating resource value flow results. Analysis tool of the former is material flow diagram and the latter is internal resources value flow cost structure.

We put forward four carbon performance indicators based on enterprise resource value flow analysis results, namely carbon cost efficiency, carbon economic efficiency, carbon reduction efficiency and carbon emission intensity. Readers can know carbon performance status of four material centers in Baosteel on 2013 from table 2. At first glance, steel rolling center has highest carbon cost efficiency, which complies resources value flow cost results before. Iron center have highest carbon intensity and carbon economic efficiency, lowest carbon cost efficiency, which means it consumed most carbon materials and consists main part of final product value. Therefore managers should try their best to improve carbon cost efficiency of iron center so as to reduce invest of carbon-based materials and reduce overall carbon emissions of enterprise.

TABLE II. CARBON PERFORMANCE EVALUATION INDICATORS OF FOUR CENTERS IN BAOSTEEL IN 2013

\begin{tabular}{|c|c|c|c|c|c|}
\hline & Unit & $\begin{array}{c}\text { Sintering } \\
\text { center }\end{array}$ & $\begin{array}{c}\text { Steel } \\
\text { center }\end{array}$ & $\begin{array}{c}\text { Iron } \\
\text { center }\end{array}$ & $\begin{array}{c}\text { Rolling } \\
\text { center }\end{array}$ \\
\hline $\begin{array}{c}\text { Carbon cost } \\
\text { efficiency }\end{array}$ & $\begin{array}{c}\text { yuan/ } \\
\text { yuan }\end{array}$ & 11.54 & 1.84 & 26.53 & 47.08 \\
\hline $\begin{array}{c}\text { Carbon } \\
\text { economic } \\
\text { efficiency }\end{array}$ & $\begin{array}{c}\text { Yuan } \\
\text { /yuan }\end{array}$ & 0.14 & 0.28 & 0.01 & 0.01 \\
\hline $\begin{array}{c}\text { Carbon } \\
\text { reduction } \\
\text { efficiency }\end{array}$ & ton/ & $4.73 \mathrm{E}-04$ & 3.76 & 2.53 & $\begin{array}{c}1.48 \mathrm{E}- \\
04\end{array}$ \\
\hline $\begin{array}{c}\text { Carbon } \\
\text { emission } \\
\text { intensity }\end{array}$ & ton/ & $8.12 \mathrm{E}-04$ & 2.03 & 2.92 & $7.02 \mathrm{E}-$ \\
& & & $\mathrm{E}-03$ & $\mathrm{E}-05$ & 05 \\
\hline
\end{tabular}

Carbon economic efficiency has overall increased eight over ten thousand. Considering small percentage and gigantic production, Baosteel didn't make great process in emission reduction. Moreover, the overall carbon cost efficiency was declined, which means Baosteel group emitted higher carbon dioxide than last year. Possible causes include price fluctuation of original fuel and other materials, decline of production efficiency. Carbon reduction efficiency didn't change too much, which may means Baosteel management hasn't take corresponding reduction actions to reduce carbon emissions in the process of enterprise production and operation. Carbon emission intensity reflects whole emission along with per positive product. There was no change between 2013 and 2014 in this indicator.

TABLE III. COMPARISON OF CARBON PERFORMANCE EVALUATION BETWEEN 2013 AND 2014

\begin{tabular}{|c|c|c|c|}
\hline & Unit & 2013 & 2014 \\
\hline Carbon cost efficiency & yuan/yuan & 6.7129 & 6.3426 \\
\hline $\begin{array}{c}\text { Carbon economic } \\
\text { efficiency }\end{array}$ & yuan/yuan & 0.0889 & 0.1013 \\
\hline $\begin{array}{c}\text { Carbon reduction } \\
\text { efficiency }\end{array}$ & ton/yuan & 0.0011 & 0.0012 \\
\hline $\begin{array}{c}\text { Carbon emission } \\
\text { intensity }\end{array}$ & ton/yuan & 0.0006 & 0.0006 \\
\hline
\end{tabular}

\section{CONCLUSIONS}

The paper analyzes carbon performance evaluation indicators and carbon performance evaluation practice and draws the following conclusions: (1) Carbon performance evaluation is an important system for the enterprises' low carbon transformation. In order to rational evaluate low carbon operation, evaluation performance theories and methods research should be deepened and strengthened. (2) Current evaluation indicators focus on comprehensive performance evaluation and overlook specific links evaluation in production process. This paper constructs evaluation indicators to reflect process performance according to production process, so there can provide more specific evaluation information. (3) Resource value flow accurately confirms positive products with value added and negative products caused by resource loss. Carbon performance evaluation indicators are made up of carbon carbon efficiency, carbon economic benefit, carbon emission reduction productivity and carbon emission intensity according to carbon flow and value flow information.

Carbon performance evaluation is a complicated problem. Comparing to current evaluation indicators, carbon performance evaluation indicators can embody characteristics of carbon emission and reduction. However, there are so many problems that need further research. For example, what measures should be taken to reduce carbon emissions for improving carbon reduction efficiency and reducing carbon emission intensity. In future research, carbon budget, carbon measurement, carbon trading and carbon performance evaluation should be combined into a comprehensive framework so as to guide carbon reduction and low carbon transformation. 


\section{ACKNOWLEDGEMENTS}

The authors would like to thank anonymous reviewers for helpful comments and the China National Social Science Foundation (Grant No.13CGL029) and Hunan Province Education Bureau Key Foundation ( Grant No.16A190) for providing financial support.

\section{REFERENCES}

[1] Z.M. Xie, "Circle economy resource value flow of coal-fired power plant,” Changsha: Central South University Doctoral Dissertation, 2012.

[2] X. Xiao and Y.L. Jin, "Resource value flow accounting construction- example,” Finance Research, Oct.2008, pp. 122-132.

[3] Y.J. Zhao, “Carbon emission cost measurement and evaluation intaking process manufacturing enterprises' circle economy as airon and steel enterprises," Changsha: Central South UniversityMaster Thesis, 2012.

[4] X.D.Tang and B.L. Zhang, "Carbon emission cost analysis from the perspective of resource value flow," Commercial Accounting, vol. 32, Apr.2013, pp. 17-20.

[5] F. Xiong and X. Xiao, "Circle economic performance measurement based on value flow," Environment Pollution and Treatment, vol. 25, May. 2014, pp.13-18. 